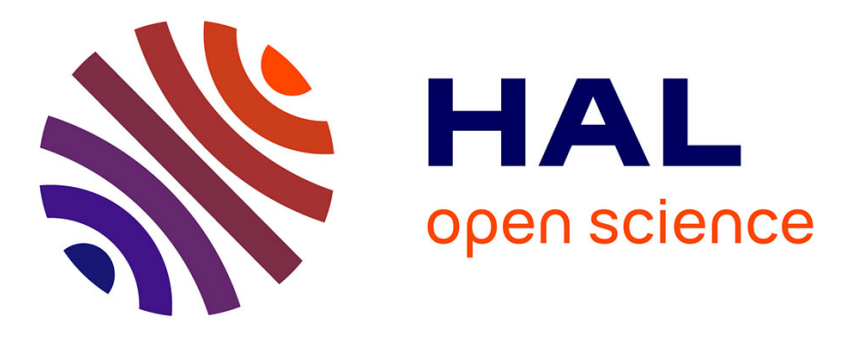

\title{
Alteration of CCK-induced satiety in post-Nippostrongylus brasiliensis-infected rats
}

Jérôme Gay-Quéheillard, L. Ressayre, Rafael Garcia Villar, Lionel Bueno, Jean Fioramonti

\section{- To cite this version:}

Jérôme Gay-Quéheillard, L. Ressayre, Rafael Garcia Villar, Lionel Bueno, Jean Fioramonti. Alteration of CCK-induced satiety in post-Nippostrongylus brasiliensis-infected rats. Brain, Behavior, and Immunity, 2003, 17, pp.35-42. hal-02680153

\section{HAL Id: hal-02680153 \\ https://hal.inrae.fr/hal-02680153}

Submitted on 31 May 2020

HAL is a multi-disciplinary open access archive for the deposit and dissemination of scientific research documents, whether they are published or not. The documents may come from teaching and research institutions in France or abroad, or from public or private research centers.
L'archive ouverte pluridisciplinaire HAL, est destinée au dépôt et à la diffusion de documents scientifiques de niveau recherche, publiés ou non, émanant des établissements d'enseignement et de recherche français ou étrangers, des laboratoires publics ou privés.

\section{()(1)(2)}

Distributed under a Creative Commons Attribution - ShareAlikel 4.0 International 


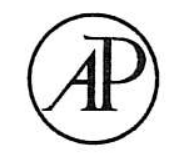

ACADEMIC PRESS

\section{Available online at www.sciencedirect.com \\ SCIENCE@DIRECT ${ }^{\circledR}$}

Brain, Behavior, and Immunity 17 (2003) 35-42
BRAIN,

BEHAVIOR, and IMMUNITY

www.elsevier.com/locate/ybrbi

\title{
Alteration of CCK-induced satiety in post-Nippostrongylus brasiliensis-infected rats
}

\author{
Jérôme Gay, Lucien Ressayre, Rafael Garcia-Villar, Lionel Bueno, \\ and Jean Fioramonti*
}

Neuro-Gastroenterology and Nutrition Unit, Institut National de la Recherche, Agronomique, 180 chemin de Tournefeuille, BP 3, 31931 Toulouse Cedex, France

Received 26 October 2001; received in revised form 27 June 2002; accepted 1 July 2002

\begin{abstract}
In rats, the nematode Nippostrongylus brasiliensis induces an intestinal inflammation, but after the inflammation had resolved and the worm burden eliminated, morphological alterations of the intestinal wall, mainly consisting of mast cell hyperplasia and enteric nerve remodeling, persist for several weeks. Intestinal signals reaching the brain through the vagus nerve and involving neuropeptides such as CCK, play a role in the control of food intake. Our hypothesis was that neuroimmune alterations of the intestine may alter this control. This work was aimed to evaluate whether post-infection alterations of the intestinal wall may affect the satiety effects of CCK and further, the role of mast cells and their mediators, histamine and serotonin, in post- $N$. brasiliensis-infected rats. In basal conditions, food intake was not different in control and post-infected groups of rats. Post-infected rats were characterized by prolonged satiety effects of both CCK and histamine but not serotonin. The prolonged effect of CCK was reduced when mast cells were previously stabilized by ketotifen, which had no effect per se on food intake. No difference was observed in the increase of food intake induced by CCK-A and CCK-B receptor antagonists in both control and post-infected rats. Mast cell degranulation with compound 48/80 induced severe anorectic effects that lasted for less than $24 \mathrm{~h}$ in post-infected rats and as long as 6 days in controls. Thus, in our experimental conditions, i.e., within 30-50 days post- $N$. brasiliensis infection, we observed an enhancement of the anorectic effect of exogenous CCK involving mast cell degranulation and histamine.
\end{abstract}

(C) 2002 Elsevier Science (USA). All rights reserved.

Keywords: Nippostrongylus brasiliensis; CCK; Satiety; Mast cells; Histamine; Serotonin

\section{Introduction}

Among the numerous factors regulating food intake, intestinal signals are known to play an important role, mainly in meal termination.

\footnotetext{
" Corresponding author. Fax: +33-561-28-53-97.

E-mail address: jiforamo(aitoulouse.inra. Ir (J. Fioramonti).
}

Cholecystokinin (CCK) is considered a major mediator involved, through vagal afferents, in the transmission of the gastrointestinal feedback signals that control meal size (Schwartz, 2000). Neuronal signals are conveyed to the central nervous system from nerve endings located at different levels of the digestive wall, from the mucosa to the serosa (Mei, 1994). These anatomical elements lead to suppose that the in- 
tegrity of the intestinal structure is a prerequisite for a normal control of food intake. Aggressions of the intestinal mucosa by chemical compounds, bacteria or parasites occur frequently and often induce functional sequels. For example, development of irritable bowel syndrome commonly occurs after bacterial gastroenteritis in humans (Neal, Hebden, \& Spiller, 1997).

Rats infected with the nematode Nippostrongylus brasiliensis provide a well-defined model or post-infective neuroimmune alterations of the small intestine. $N$. brasiliensis induces an acute inflammation in the jejunum whose intensity peaks 12-14 days after infection (Castex et al,, 1998). This inflammation is characterized by mucosal lesions that consist of villus atrophy and crypt hyperplasia, associated with mast cell activation and leukotriene generation (Arizono \& Nakao, 1988; Perdue, Ramage, Burget, Marshall, \& Masson, 1989). Thirty days after infection, jejunal inflammation has resolved but mucosal mast cell hyperplasia (Gay, Fioramonti, Garcia-Villar, \& Bueno, 2000) and a profound enteric nerve remodeling persist for several weeks (Newlands, Miller, MacKellar, \& Galli, 1995; Stead, Kosecka-Janiszewska, Oestreicher; Dixon, \& Bienenstock, 1991; Stead, 1992).

Since mast cells produce mediators, such as histamine and serotonin, involved in the control of food intake, disturbances of food intake associated with intestinal mast cell hyperplasia can be supposed. However, the relationships between mast cells and food intake have been poorly investigated. Only one study indicates a swelling of mesentery mast cells during feeding in the rat, an effect mediated through parasympathetic efferent nerves (Rothschild \& Gomes, 1988). More interestingly, it has been shown that nutrients which are potent releasers of CCK, such as ovalbumin hydrolyzate, degranulate intestinal mucosal mast cells, an effect mediated through CCK-B receptors (Juanola, Giralt, Jimenez, Mourelle, \& Vergara, 1998). Moreover, this CCK-induced mast cell degranuiation is involved in the action of CCK to induce a post-prandial pattern of intestinal motility (Juanola et al., 1998).

On the other hand, mast cells are considered key cells in intestinal neuroimmune interactions. There is a close apposition between mast cells and sensory nerve fibers (Stead et al., 1987) and an important number of these fibers are vagal fibers, which provide an anatomical basis for a direct neural communication between intestinal mast cells and the central nervous system (Williams, Berthoud, \& Stead, 1997). In addition, the number of jejunal mast cells in close association with neural processes is increased by $60 \%$ after $N$. brasiliensis infection in the rat (Arizono et al., 1990).

Taken together, all these elements lead to supose that the control of food intake by CCK, which involves a vagal pathway, may be altered after infection by $N$. brasiliensis in rats. Therefore, this work was aimed to evaluate the alterations of the effects of CCK on food intake in post-N. brasiliensis-infected rats. We also evaluated the role of mast cells and of two of their mediators, histamine and serotonin (5-HT), in these alterations.

\section{Materials and methods}

\section{2,1. Animals}

Groups of 20 male Wistar rats (10 control groups and 10 post- $N$. brasiliensis-infected groups; Harlan, Ganat, France), initially weighing between 200 and $250 \mathrm{~g}$, were used for these experiments. Rats were housed in individual polypropylene cages under controlled lighting and temperature $\left(21 \pm 1^{\circ} \mathrm{C}\right)$ and accustomed to receive a standard diet (A04, Usine d'Alimentation Rationnelle, Epinay-sur-Orge, France) between 10 a.m. and 2 p.m. for 15 days before experiments. Tap water was provided ad libitum. All animal procedures were approved by the Local Animal Care and Use Committee of the Institut National de la Recherche Agronomique.

\subsection{Culture and infection techniques}

N. brasiliensis was maintained in continuous culture by harvesting worm eggs from infected rats and growing them to the third larval (L3) stage on vermiculite and filter paper, using a technique described by Jennings, Mulligan, and Urquhart (1963). The appropriate rats were infected by subcutaneous injection of $3000 \mathrm{~L} 3$ infective larvae of $N$. brasiliensis in $.5 \mathrm{ml}$ sterile saline into the flank. Controls received $.5 \mathrm{ml}$ sterile saline.

\subsection{Experimental design}

For each series of experiments, treatments were applied in parallel to both control and postfats. Rats received food pellets only between $10 \mathrm{am}$. and 2 p.m. Food intake was quantified by weighing food pellets each $30 \mathrm{~min}$ for $4 \mathrm{~h}$. Experiments were carried out between 30 and 50 days post- $N$. brasiliensis infection. 
CCK $(50 \mu \mathrm{g} / \mathrm{kg})$, serotonin $(5-\mathrm{HT} ; 5 \mathrm{mg} / \mathrm{kg})$, and histamine $(2 \mathrm{mg} / \mathrm{kg})$ were injected by intraperitoneal (i.p.) route just before feeding the rats. Devazepide $(500 \mu \mathrm{g} / \mathrm{kg}$, i.p.) and L-365260 $(500 \mu \mathrm{g} / \mathrm{kg}$, i.p. $)$, respectively, CCK-A and CCK-B receptor antagonists, were administered $30 \mathrm{~min}$ before feeding. The mast cell degranulator, compound $48 / 80(1 \mathrm{mg} / \mathrm{kg}$, i.p.), was injected $1 \mathrm{~h}$ before feeding. The mast cell stabilizer, ketotifen, was given for 4 days $(1 \mathrm{mg} / \mathrm{kg}$, i.p., b.i.d.), with the last injection being given $30 \mathrm{~min}$ before feeding.

\subsection{Chemicals}

Sulfated CCK-8, ketotifen fumarate, compound 48/80, 5-HT, and histamine were from Sigma (St. Louis, MO, USA) and dissolved in sterile saline. Devazepide and L-365260 were provided by Merck Research Laboratories (Rahway, NJ, USA) and dissolved in dimethyl sulfoxide.

\subsection{Data analysis}

Food consumption was expressed both in grams of eaten food per $100 \mathrm{~g}$ of body weight (Table 1) and normalized to the percentage of food eaten by treated rats compared with that eaten by rats treated with the corresponding vehicle taken as $100 \%$ (Figs. 1-6). Results were expressed as means \pm SEM for each group. Statistical analyses were performed using analysis of variance (ANOVA), followed by multiple comparison post-test or Student's $t$ test where appropriate. $p<.05$ was considered statistically significant.

\section{Results}

\subsection{Basal conditions}

No differences in the amounts of food eaten by rats fed during four hours (thereafter termed
" 4 h-food intake") were observed between controls and post- $N$. brasiliensis-infected rats (Table 1).

\subsection{Effects of CCK alone}

During the first $30 \mathrm{~min}, \mathrm{CCK}(50 \mu \mathrm{g} / \mathrm{kg}) \mathrm{re}-$ duced food intake in both control and post-infected rats down to $8.7 \pm 3.3$ and $6.0 \pm 1.3 \%$ $p>.05$ of food intake in vehicle-treated rats (thereafter termed "vehicle"), respectively. The anorectic effect of CCK was maintained for the following $30 \mathrm{~min}$ in post-infected rats $(32.5 \pm 8.3 \%)$ but not in controls $(95.1 \pm 23.4 \% ; p<.05)$ (Fig. 1$)$.

\subsection{Effects of CCK after ketotifen treatment}

Ketotifen given alone $(1 \mathrm{mg} / \mathrm{kg}$, i.p., b.i.d. $)$ had no effect per se on food intake in both control and post-infected rats during the first hour of feeding (Fig. 2). After ketotifen treatment, the anorectic effect of CCK $(50 \mu \mathrm{g} / \mathrm{kg})$ remained unchanged during the first $30 \mathrm{~min}$ in both control and postinfected rats (Fig. 1A) but was reduced for the following $30 \mathrm{~min}$ in post-infected rats $(69.9 \pm 8.5 \mathrm{vs}$ $32.5 \pm 8.3 \%$ after CCK alone; $p<.05$ ) (Fig. 1B).

\subsection{Effects of 5-HT}

At the dose of $5 \mathrm{mg} / \mathrm{kg}$ i.p., 5-HT significantly reduced food intake $(p<.05)$ during the first hour of feeding. No significant difference $(p>.05)$ was observed between control and post-infected rats (Fig. 2).

\subsection{Effects of histamine}

Histamine $(2 \mathrm{mg} / \mathrm{kg})$ reduced food intake to a similar extent in both control and post-infected rats for the first $30 \mathrm{~min}$ of feeding. Reduced food intake, however, persisted for the following $30 \mathrm{~min}$ in post-infected but not in control rats (Fig. 3).

Table 1

Average body weight and food intake for $4 \mathrm{~h}$ after saline administration in control and post- $N$. brasiliensis-infected rats, 30 and 50 days post-infection

\begin{tabular}{llllll}
\hline & \multicolumn{2}{l}{ Controls } & & \multicolumn{2}{l}{ Post-infected } \\
\cline { 2 - 3 } \cline { 5 - 6 } & $\begin{array}{l}\text { Weight } \\
(\mathrm{g})\end{array}$ & $\begin{array}{l}\text { Food intake } \\
(\mathrm{g} / 4 \mathrm{~h})\end{array}$ & & $\begin{array}{l}\text { Weight } \\
(\mathrm{g})\end{array}$ & $\begin{array}{l}\text { Food intake } \\
(\mathrm{g} / 4 \mathrm{~h})\end{array}$ \\
\hline Thirty days post-infection & $210.1 \pm 3.5$ & $16.4 \pm .6$ & & $221.9 \pm 6.3$ & $16.0 \pm .5$ \\
Fifty days post-infection & $251.0 \pm 4.6$ & $15.2 \pm .6$ & & $252 \pm 5.8$ & $15.3 \pm .7$ \\
\hline
\end{tabular}
rats).

(Values represent means \pm SEM. No significant difference $(p>, 05)$ was observed between post-infected and control 


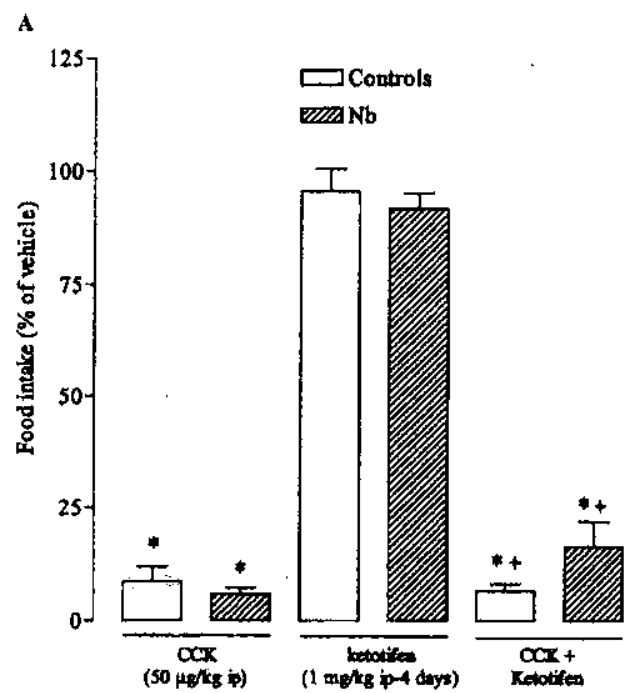

B

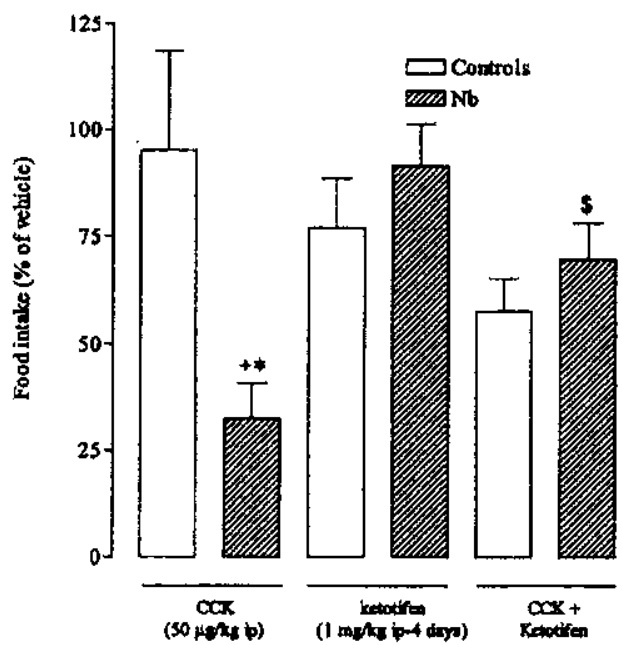

Fig. 1. Effect of CCK $(50 \mu g / \mathrm{kg}$, i.p), ketotifen $(1 \mathrm{mg} / \mathrm{kg}$ i.p., 4 days, b.i.d.), and CCK after ketotifen treatment on food intake in controls and post- $N$. brasiliensis-infected rats during the $0-30 \mathrm{~min}$ (A) and $30-60 \mathrm{~min}$ (B) periods after CCK administration. Values are expressed in percentage of food intake of vehicle-treated rats (means $\pm \mathrm{SEM} ; n=10 ;{ }^{*} p<.05$ compared to vehicle $(100 \%) ;+p<.05$ compared to respective controls; $\$ p<.05$ compared to CCK alone).

\subsection{Effects of $C C K$ receptor antagonists}

Both devazepide and L-365260 (500 $\mu / \mathrm{kg}$, i.p.) significantly $(p<.05)$ increased food intake during the first $30 \mathrm{~min}$ in control and post-infected rats. This increase remained significant $(p<.05)$

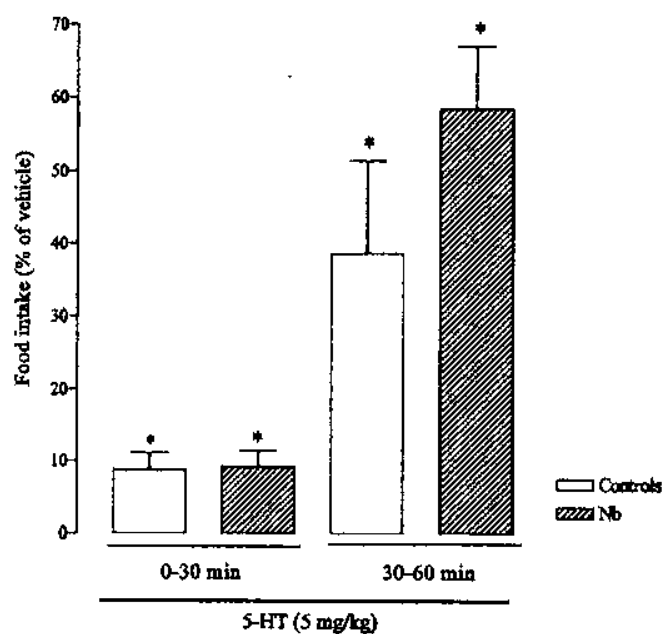

Fig. 2. Effect of $5-H T(5 \mathrm{mg} / \mathrm{kg}$, i.p.) on food intake in control and post- $N$. brasiliensis-infected rats during the $0-30$ and $30-60 \mathrm{~min}$ periods after $5-\mathrm{HT}$ administration. Values are expressed in percentage of food intake of vehicle-treated rats (means $\pm \mathrm{SEM} ; n=10 ;{ }^{*} p<.05$ compared to vehicle, $100 \%$ ).

within the $4 \mathrm{~h}$ of feeding and was similar $(p>.05)$ in both groups (Fig. 4).

\subsection{Effect of mast cell degranulation}

Compound $48 / 80$ given i.p. $1 \mathrm{~h}$ before feeding strongly reduced the $4 \mathrm{~h}$-food intake of both control and post-infected rats. No difference $(p>.05)$ was observed in the responses of both groups. In control rats, however, the effect of $48 / 80$ was longer, with a return to $100 \%$ food intake (i.e., that obtained in rats given the vehicle of compound 48/80) only at the seventh day after $48 / 80$ administration. In post-infected rats, $100 \%$ food intake was recovered at $24 \mathrm{~h}$ after $48 / 80$ (Fig. 5). After ketotifen treatment, the anorectic effect of compound $48 / 80$ was significantly reduced $(p<.05)$ in controls and abolished in post-infected rats (Fig. 6), while 100\% food intake was recovered at $24 \mathrm{~h}$ after compound $48 / 80$ in both groups (not shown).

\section{Discussion}

Our results indicate that the reduction of food intake induced by exogenous CCK is prolonged in post- $N$. brasiliensis-infected rats and bring evidence for the involvement of mast cells because this effect was blocked by the mast cell stabilizer, ketotifen. So far, only few studies indicate that 


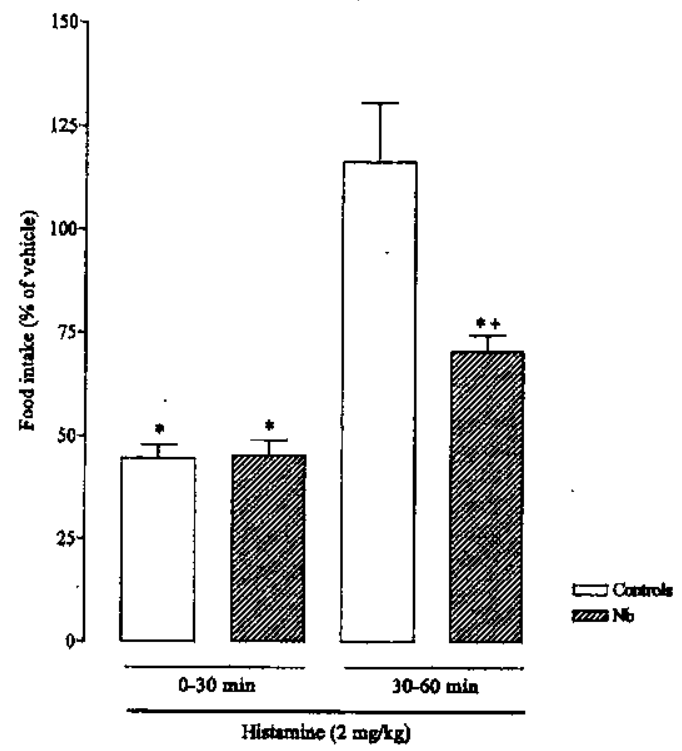

Fig. 3. Eflect of histamine $(2 \mathrm{mg} / \mathrm{kg}$, i.p.) on food intake in control and post- $N$. brasiliensis-infected rats during the $0-30$ and $30-60 \mathrm{~min}$ periods after histamine administration. Values are expressed in percentage of food intake of vehicle-treated rats (means \pm SEM; $n=10$; ${ }^{*} p<.05$ compared to vehicle $(100 \%) ;+p<.05$ com. pared to respective controls).

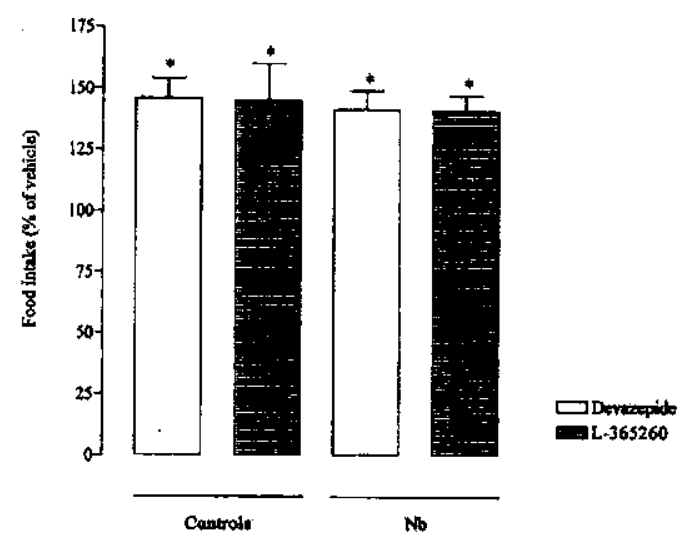

Fig. 4. Effect of CCK-A (devazepide; $500 \mu \mathrm{g} / \mathrm{kg}$, i.p.) and CCK-B (L-365260; $500 \mu g / k g$, i.p.) receptor antagonists on the $4 \mathrm{~h}$-food intake in controls and post- $N$. brasiliensis-infected rats. Values are expressed in percentage of food intake of vehicle-treated rats (means $\pm S E M ; n=10 ;{ }^{*} p<.05$ compared to vehicle, $100 \%)$.

post-prandial gastrointestinal hormones degranulate mast cells. Thus, it has been reported that gastrin stimulates gastric mucosal mast cells (Plebani et al., 1995) and that endogenous CCK, released by an ovalbumin hydrolyzate, degranulates

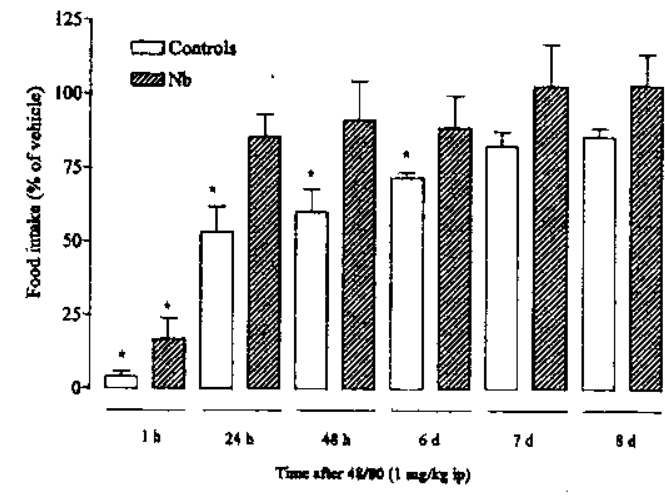

Fig. 5. Effect of the mast cell degranulator, compound $48 / 80(1 \mathrm{mg} / \mathrm{kg}$, i.p.), on the $4 \mathrm{~h}$-food intake measured at different times within the 8-day period following its administration in control and post- $N$. brasiliensis-infected rats. Values are expressed in percentage of food intake of vehicle-treated rats (means \pm SEM; $n=10 ;{ }^{*} p<.05$ compared to vehicle, $100 \%$ ).

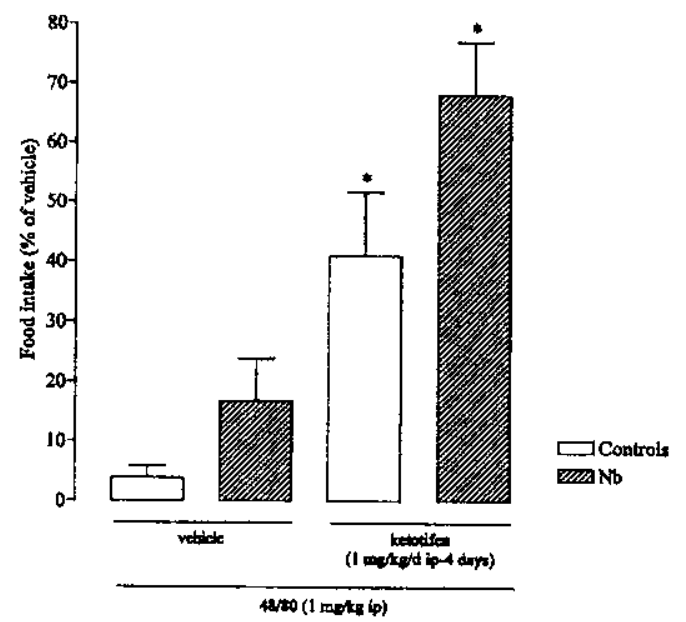

Fig. 6. Effect of compound $48 / 80(1 \mathrm{mg} / \mathrm{kg}$, i.p.) on the $4 \mathrm{~h}$-food intake in saline- and ketotifen-treated control and post- $N$. brasiliensis-infected rats. Values are expressed in percentage of food intake of vehicle-treated rats (means $\pm \mathrm{SEM} ; n=10 ;{ }^{*} p<.05$ compared to vehicle, $100 \%)$.

mucosal mast cells (Juanola et al., 1998). However, CCK receptors have never been identified on intestinal mast cells and an indirect action through a neuronal pathway can be postulated to explain CCK-induced mast cell degranulation. CCK-A and $\mathrm{CCK}-\mathrm{B}$ receptors have been found localized on vagal afferent neurons (Moriarty, Dimaline, Thompson, \& Dockray, 1997), which are known to be in close apposition with mast cells (Williams 
et al., 1997). However, we suppose that the satietogenic effect of CCK depends upon mast cell degranulation in post-infected rats but not in controls, since the mast cell stabilizer ketotifen was active only in post-infected rats. This can be due to functional differences between intestinal mast cells of naive rats and those resulting from the hyperplasia induced by nematode infection. For example, the expression of mouse mast cell protease-1 has been found up-regulated in $N$. brasiliensis-infected mice (Scudamore et al., 1997). Similarly, $N$. brasiliensis infection enhances expression of the $\beta$-subunit of the mast cell $\mathrm{Fc}$ epsilon IgE receptor (Shaikh et al., 1997). Also, CCK-induced mast cell degranulation in post-infected rats can be explained by intrinsic nerve remodeling associated with mast cell hyperplasia, with the proportion of mast cells in close contact with afferent neurons being strongly increased after $N$. brasiliensis infection (Arizono et al., 1990).

We also found that serotonin inhibited food intake in a manner similar to that in control and post-infected rats. The absence of difference was unexpected for several reasons: first, serotonin is produced by rat mast cells; second, several interactions between CCK-ergic and serotoninergic control of food intake have been reported (EberleWang, Levitt, \& Simansky, 1993; Poeschla, Gibbs, Simansky, Greenberg, \& Smith, 1993); and third, serotonin has been found responsible for alterations of digestive functions induced by mast cell degranulation (Bueno, Fargeas, Theodorou, \& Fioramonti, 1991; Castex, Fioramonti, Fargeas, More, \& Bueno, 1994). On the other hand, histarnine reproduced the inhibition of food intake induced by CCK during the second $30 \mathrm{~min}$ period of the $4 \mathrm{~h}$-feeding time. This suggests that histamine may be the mast cell mediator involved in the effects of CCK on food intake in post-infected rats. This is in agreement with the involvement of $\mathrm{H} 1, \mathrm{H} 2$, and $\mathrm{H} 3$ histamine receptors in the CCK inhibition of food intake in rats (Attoub et al., 2001) However, the histaminergic system is known to be implicated in control of food intake at the level of the central nervous system. Consequently, since histamine induced different effects in control and post-infected rats, then alterations of the central histaminergic system in post-infected rats can be speculated. The histaminergic activity of the central nervous system has been reported to be involved in the anorexia seen in protein malnutrition, which leads to elevated histamine $\mathrm{H} 1$ receptors (Mercer, Kelley, Haq, \& Humphries, 1996). Interestingly, N. bra- siliensis infection has been found associated with an impairment of protein digestion (Symons \& Jones, 1970), which could alter H1 receptors in the central nervous system.

Our data confirm the increase in food intake that was already observed after administration of a CCK-A receptor antagonist (Corwin, Gibbs, \& Smith, 1991). Enhanced food intake has also been reported with CCK-B receptor antagonists injected intracerebroventricularly (Dorre \& Smith, 1998) whereas L-365260 was administered i.p. in our study. However, both devazepide and L-365260 apparently exhibit good blood-brain barrier penetration (Patel, Chapman, Heald, Smith, \& Freedman, 1994; Pullen \& Hodgson, 1987) and a central site of action can be postulated for the two compounds. The absence of difference in the increase of food intake in control and post-infected rats suggests that $N$. brasiliensis infection did not alter the central CCK-ergic control of food intake. In addition, it is well established that the satiety effect of CCK involves the vagus nerve (Lorenz \& Goldman, 1982), but the involvement of vagal afferents has been shown to account for the effects of peripherally administered exogenous CCK, but not for those of endogenous CCK. The fact that the effect of exogenous but not endogenous CCK differing in control and post-infected rats may be attributed to $N$. brasiliensis-induced intestinal nerve remodeling, which increases the association of mast cells with neural afferent processes (Arizono et al., 1990).

We found that massive degranulation of mast cells by compound $48 / 80$ reduced food intake for one week in control rats. This long-lasting effect is consistent with the decrease in food intake induced by mast cell degranulation in other experimental conditions. For example, in rats sensitized to egg albumin, chronic antigen challenge resulted in the degranulation of mucosal mast cells associated with reduced food intake (Curtis, Patrick, CattoSmith, \& Gall, 1990). In another model, inhibition of food intake by Escherichia coli lipopolysaccharide was prevented by mast cell stabilization with sodium cromoglycate (Nava \& Caputi, 1999). In post- $N$. brasiliensis-infected rats, the effects of $48 /$ 80 on food intake were limited to the day of administration. However, only speculations can be proposed to explain the absence in post-infected rats of the long-lasting effect of compound $48 / 80$ on food intake observed in control rats. Compound $48 / 80$ can act directly on mast cells, but also on peripheral endings of capsaicin-sensitive primary afferent neurons to degranulate mast cells, at least in the urinary bladder (Eglezos et al., 1992). 
The infection-induced nerve remodeling could explain the reduced duration of $48 / 80$ in post-infected rats, assuming that the neo-innervation would not be able to degranulate mast cells. Another hypothesis could be that mast cells arising from $N$. brasiliensis infection are less sensitive to the action of compound 48/80; these mast cells are mucosal mast cells (Shanahan, Denburg, Fox, Bienenstock, \& Befus, 1985), which are known to be relatively insensitive to $48 / 80$ (Metcalfe, Baram, \& Mekori, 1997); however, compound 48/80 was administered i.p. in our study and, consequently, did not affect only intestinal mast cells.

In conclusion, our data show that $N$. brasiliensis infection induces long-term changes in the control of food intake in rats during the post-infective stage, i.e., after intestinal inflammation has resolved and the worm burden eliminated. Our results support the participation of intestinal mast cells in the mechanisms of regulation of food ingestion by CCK and suggest histamine as a mediator contributing to the prolonged anorectic action of CCK intestinal infection in rats.

\section{Acknowledgments}

The authors acknowledge the financial support of INRA (Grant PAS 64) and Fondation pour la Recherche Médicale (FRM).

\section{References}

Arizono, N., Matsuda, S., Hattori, T., Kojima, Y., Maeda, T., \& Galli, S. J. (1990). Anatomical variation in mast cell nerve associations in the rat small intestine, heart, lung, and skin. Similarities of distances between neural processes and mast cells, eosinophils, or plasma cells in the jejunal lamina ptopria. Lab. Invest., 62, 626-634.

Arizono, N., \& Nakao, S. (1988). Kinetics and staining properties of mast cells proliferating in rat small intestine tunica muscularis and subserosa following infection with Nippostrongylus brasiliensis. APMIS, 96, 964-970.

Attoub, S., Moizo, L., Sobhani, I., Laigneau, J. P., Lewin, M. J., \& Bado, A. (2001). The H3 receptor is involved in cholecystokinin inhibition of food intake in rats. Life Sci, 69, 469-478.

Bueno, L., Fargeas, M. J., Theodorou, V., \& Fioramonti, J. (1991). Involvement of 5-hydroxytryptamine in the intestinai motor disturbances induced by mast ceil degranulation in rats. Eur. $J$, Pharmacol, $192,263-269$.
Castex, N., Fioramonti, J., Ducos de Lahitte, J., Luffau, G., More, J., \& Bueno, L. (1998). Brain Fos expression and intestinal motor alterations during nematode-induced inflammation in the rat. $A m$. $J$. Physiol, 274, G210-G216.

Castex, N., Fioramonti, J., Fargeas, M. J., More, J., \& Bueno, L. (1994). Role of 5-HT3 receptors and afferent fibers in the effects of mast cell degranulation on colonic motility in rats. Gastroenterology, 107, 976-984.

Corwin, R. L., Gibbs, J., \& Smith, G. P. (1991). Increased food intake after type A but not type B cholecystokinin receptor blockade. Physiol. Behav., 50, 255-258.

Curtis, G. H., Patrick, M. K., Catto-Smith, A. G., \& Gall, D. G. (1990). Intestinal anaphylaxis in the rat Effect of chronic antigen exposure. Gastroenterology, $98,1558-1566$.

Dorre, D., \& Smith, G. P. (1998). Cholecystokinin B receptor antagonist increases food intake in rats. Physiol. Behav., 65, 11-14.

Eberle-Wang, K., Levitt, P., \& Simansky, K. J. (1993). Abdominal vagotomy dissociates the anorectic mechanisms for peripheral serotonin and cholecystokinin. Am. J. Physiol., 265, R602-R608.

Eglezos, A., Lecci, A., Santicioli, P., Giuliani, S., Tramontana, M., Del Bianco, E., \& Maggi, C. A. (1992). Activation of capsaicin-sensitive primary afferents in the rat urinary bladder by compound 48/80; A direct action on sensory nerves? Arch Int. Pharmacodyn. Ther, '315, 96-109.

Gay, J., Fioramonti, J., Garcia-Villar, R., \& Bueno, L. $(2000)$. Alterations of intestinal motor responses to yarious stimuli after Nippostrongylus brasiliensis infection in rats: Role of mast cells. Neurogastroenterol. Motil., 12, 207-214.

Jennings, F. W., Mulligan, W., \& Urquhart, G. M. (1963). Variables in X-ray inactivation of Nippostrogylus brasiliensis larvae. Exp. Parasitol, 13, 367373.

Juanola, C., Giralt, M., Jimenez, M., Mourelle, M., \& Vergara, P, (1998). Mucosal mast cells are involved in CCK disruption of MMC in the rat intestine. Am. J. Physioh, 275, G63-G67.

Lorenz, D. N., \& Goldman, S. A. (1982). Vagal mediation of the cholecystokinin satiety effect in rats. Physiol. Behav., 29, 599-604.

Mei, N. (1994). Role of the digestive afferents in food intake regulation. In C. R. Legg, \& D. Booth (Eds.) Appetite, neural and behavioural bases (pp. 86-97). Oxford: Oxford University Press.

Mercer, L. P., Kelley, D. S., Haq, A., \& Humphries, L. L. (1996). Dietary induced anorexia: A review of involvement of the histaminergic system. Am. Coll. Nutr., 15, 223-230.

Metcalfe, D. D., Baram, D., \& Mekori, Y. A. (1997). Mast ceils. Physiol, Rev., 77, 1033-1079.

Moriarty, P., Dimaline, R., Thompson, D. G., \& Dockray, G. J. (1997). Characterization of chole- 
cystokinin A and cholecystokinin B receptors expressed by vagal afferent neurons. Neuroscience, $79,905-913$.

Nava, F., \& Caputi, A. P. (1999). Central effects of cromoglycate sodium salt in rats treated with lipopolysaccharide. Eur. $J$, Pharmacol, 367, 351-359.

Neal, K. R., Hebden, J., \& Spiller, R. (1997). Prevalence of gastrointestinal symptoms six months after bacterial gastroenteritis and risk factors for development of the irritable bowel syndrome: Postal survey of patients. Brit. Med. J., 317, 779-782.

Newiands, G. F., Miller, H. R., MacKellar, A., \& Galli, S. J. (1995). Stem cell factor contributes to intestinal mucosal mast cell hyperplasia in rats infected with Nippostrongylus brasiliensis or Trichinella spiralis, but anti-stem cell factor treatment decreases parasite egg production during $N$. brasiliensis infection. Blood, 86, 1968-1976.

Patel, S., Chapman, K. L., Heald, A., Smith, A. J., \& Freedman, S. B. (1994). Measurement of central nervous system activity of systemically administered CCK B receptor antagonists by ex vivo binding. Eur. J. Pharmacol., 253, 237-244.

Perdue, M. H., Ramage, J. K., Burget, D., Marshall, J., \& Masson, S. (1989). Intestinal mucosal injury is associated with mast cell activation and leukotriene generation during Nippostrongylus-induced inflammation in the rat. Dig. Dis. Sci., 34, 724-731.

Plebani, M., Basso, D., Busatto, G., Brigato, L. Battistel, M., \& Rugge, M. (1995). Gastrin stimulates gastric mast cells in rabbits. Res. Exp. Med, 195, 365-371.

Poeschla, B., Gibbs, J., Simansky, K. J., Greenberg, D., \& Smith, G. P. (1993). Cholecystokinin-induced satiety depends on activation of 5-HT1C receptors. Am. J. Physiol., 264, R62-R64.

Pullen, R. G., \& Hodgson, O. J. (1987). Penetration of diazepam and the non-peptide CCK antagonist, L364,718, into tat brain. J. Pharm. Pharmacol., 39, 863-864.

Rothschild, A. M., \& Gomes, E. L. (1988). Atropine and hexamethonium-sensitive, $\mathrm{Ca} / \mathrm{K}$-modulated, reversible swelling of mast cells in rat mesentery, due to feeding or exposure to carbachol. Agents Actions, 25, 4-10.

Schwartz, G. J. (2000). The role of gastrointestinal yagal afferents in the control of food intake: Current prospects. Nutrition, 16, 866-873.

Scudamore, C. L., McMillan, L., Thornton, E. M., Wright, S. H., Newlands, G. F., \& Miller, H. R (1997). Mast cell heterogeneity in the gastrointestinal tract: Variable expression of mouse mast cell protease-1 (mMCP-1) in intraepithelial mucosal mast cells in nematode-infected and normal BALB/c mice. Am J. Pathol, 150, 1661-1672.

Shaikh, N., Rivera, J., Hewlett, B. R., Stead, R. H., Zhu, F. G., \& Marshall, J. S. (1997). Mast cell Fc epsilon RI expression in the rat intestinal mucosa and tongue is enhanced during Nippostrongylus brasiliensis infection and can be up-regulated by in vivo administration of IgE. J. Immunol, 158, 3805-3812.

Shanahan, F., Denburg, J. A., Fox, J., Bienenstock, J., \& Befus, D. (1985). Mast cell heterogeneity: Effects of neuroenteric peptides on histamine release. $J$. Immunol, 135, 1331-1337.

Stead, R. H. (1992). Nerve remodelling during intestinal inflammation. Ann. NY Acad. Sci. 664, 443-455.

Stead, R. H., Kosecka-Janiszewska, U., Oestreicher, A. B., Dixon, M. F., \& Bienenstock, J. (1991). Remodeling of B-50 (GAP-43)- and NSE-immunoreactive mucosal nerves in the intestines of rats infected with Nippostrongy/us brasiliensis. J. Neurosch, 11, 38093821.

Stead, R. H., Tomioka, M., Quinonez, G., Simon, G. T., Felten, S. Y., \& Bienenstock, J. (1987). Intestinal mucosal mast cells in normal and nematode-infected rat intestines are in intimate contact with peptidergic nerves. Proc. Natl. Acad Sci. USA, 84, 2975-2979.

Symons, L. E., \& Jones, W. O. (1970). Nematospiroides dubius, Nippostrongylus brasiliensis, and Trichostrongylus colubriformis: Protein digestion in infected mammals. Exp. Parasitol., 27, 496-506.

Williams, R. M., Berthoud, H. R., \& Stead, R. H. (1997). Vagal afferent nerve fibres contact mast cells in rat small intestinal mucosa. Neuroimmunomodulation, 4, 266-270. 